Table I shows that most wheat leaves remained healthy when grown together with $P$. hydropiper. Nothing is known of the way in which $P$. hydropiper influences $A$. tritici, but possibly its root diffusates are toxic and prevent emerging larvae from moving and invading the host plants. Fewer leaves were produced by the wheat plants when they were grown together with Polygonum, probably because of competition for light, water and nutrients, but toxic root diffusates may also have been involved.

I thank Dr A. Morgan Golden, US Department of Agriculture, Beltsville, for wheat galls and grains and Dr R. P. Purkayastha, Department of Botany, Visva-Bharati University, for his help.

Department of Zoology,

N. C. SUkuL

Visva-Bharati University,

Santiniketan, W. Bengal, India.

Received September 4; revised October 16, 1969.

1 Trimitt, M. J., J. Helminthol., 7, 81 (1928).

- Ellenby, C., Ann. Appl. Biol., 38, 859 (1951).

s Slootweg, A. F. G., Nematologica, 1, 192 (1956).

- Rohde, R. A., and Jenkins, W. R., Phytopathology, 48, 463 (1958).

${ }^{-}$Rohde, R. A., in Nematology, Frundamentals and Recent Advances with Emphasis on Plant Parasitic and Soil Forms (edit. by Sasser, J. N., and Jenkins, W. R.), 447 (University of North Carolin
Sukul, N. C., Proc. Zool. Soc., Calcutla (in the press).

7 Leukel, R. W., US Dept Agric. Farmers Bull., 1607 (revised), 1 (1957).

' Bacrmann, G., Tijdsch. Geneesk. Ned.-Ind., 5\%, 131 (1917).

\section{Effect of Cobalt Applications to Pasture on Herbage Digestibility}

Trie importance and essential role of vitamin $\mathrm{B}_{12}$ and cobalt, its precursor, in ruminant nutrition and metabolism have been described ${ }^{1-3}$. Cobalt deficiency in sheep results in marked changes in the rumen microflora ${ }^{4}$, and although some difforence in the efficiency of fibre digestion may thus be expected to follow, there is little evidence to support this. Marston et al. ${ }^{2}$ state that the rate and course of carbohydrate fermentation are unaffected by low cobalt levels in the rumen. Other workers have reported that cobalt supplements increased the digestibility of fibre ${ }^{5,8}$, while Becker and Smith $^{7}$ found fibro digestibility to be reduced by cobalt supplementation, although the digestibility of ether extract and nitrogenfree extract increased.

This communication presents evidence of a substantial increase in digestibility after the application of small quantities of cobalt to pasture. Chemical analysis of Italian ryegrass (var. RVP) an perennial ryegrass (var. Reveille) showed both grasses to have a low cobalt content. Cobalt sulphate solution was thereforo sprayed in carly March on to half of each pasture (200 g Co por ha) ( + Co) the other half being left untreated $(-\mathrm{Co})$. Eight weeks after spraying, the grasses were harvested separately and artificially dried. The application of cobalt had no effect on horbage growth or on its botanical composition. Chemical analysis showed nitrogen $(2 \cdot 0-2 \cdot 2$ per cent) and fibre (26.5-28.6 per cent) contents to be similar for both varieties and to be unaffected by the cobalt application. Both varieties seemed to contain nutritionally adequate quantities of minerals othor than cobalt, although Reveille showed a low content of calcium $(0 \cdot 27$ per cent). Cobalt application significantly increased herbage cobalt content (Table 1) and, on the basis of published estimates ${ }^{8}$, the untreated RVP was deficient, and the untreated Reveille marginally adequate, for lambs.

The artificially dried grasses were offered to four grouns of six (three month old) lambs for nine wceks before digestibility was determined. No significant difference in the amount of feed consumed per day occurred between tho groups offered the $+\mathrm{Co}$ and $-\mathrm{Co}$ herbages of either variety. For the first six weeks, lambs offered the +Co and - Co Reveille herbages gained weight at the same rate, but in the last three weeks the + Co group gained significantly more weight $(P=0 \cdot 01)$. There was no difference in the live weight gain of lambs offered the + Co and - Co RVP herbages.

After nine weeks the digestibility of each herbage was estimated, using three lambs from each of tho four groups in the previous cxperiment. Faeces and urine were collected for eight days after a preliminary feeding period of ton days, and the lambs had therefore been offered the experimental feeds for over ten weeks before digestibility was determined. The digestibility of dry matter, organic matter and fibre was significantly higher $(P=0 \cdot 01)$ for the + Co than for the - Co Revoille herbages, but there was no difference in digestibility between the $+\mathrm{Co}$ and $-\mathrm{Co}$ RVP herbages (Table 1). There were no significant, differences between treatments in intake of feed.

Table 1. COBALT CONTENT, DRF MATTER INTAKE AND DIGESTIBILITY OF THE TXPERTMTENTAY TEEDS

\begin{tabular}{|c|c|c|c|c|c|}
\hline & & & & & \\
\hline & & & Mean v & Ines for th & ee lambs \\
\hline Feeds & $\begin{array}{c}\text { Co } \\
\text { content } \\
\text { (p.y.m.) }\end{array}$ & $\begin{array}{c}\text { Intake } \\
\text { (g } \mathrm{KgW}^{\mathbf{0 , 7 3}} \\
\text { per day) }\end{array}$ & $\begin{array}{l}\text { Percent- } \\
\text { 'age of } \\
\text { dry } \\
\text { matter } \\
\text { digested }\end{array}$ & $\begin{array}{l}\text { Perfent- } \\
\text { age of } \\
\text { organic } \\
\text { matter } \\
\text { digested }\end{array}$ & $\begin{array}{l}\text { Percent- } \\
\text { age of } \\
\text { fibre } \\
\text { digested }\end{array}$ \\
\hline $\begin{array}{r}\mathrm{VP}+\mathrm{Co} \\
-\mathrm{Co}\end{array}$ & $\begin{array}{l}0.25 \\
0.06,+\end{array}$ & $\left.\begin{array}{l}69 \\
59\end{array}\right\} N S$ & $\left.\begin{array}{l}67 \\
67\end{array}\right) N S$ & $\left.\begin{array}{l}70 \\
69\end{array}\right\} \mathrm{Ns}$ & $\left.\begin{array}{l}60 \\
62\end{array}\right\} N S$ \\
\hline$E$. of difference & $0 \cdot 01$ & $4 \cdot 3$ & 0.50 & 0.68 & 1.96 \\
\hline $\begin{array}{r}\text { veille }+ \text { Co } \\
- \text { Co }\end{array}$ & $\left.\begin{array}{l}0.27 \\
0.11\end{array}\right\}+$ & $\left.\begin{array}{l}58 \\
61\end{array}\right\} N S$ & $\left.\begin{array}{l}72 \\
66\end{array}\right\} *$ & $\left.\begin{array}{l}74 \\
69\end{array}\right\} *$ & $\left.\begin{array}{c}72 \\
65\end{array}\right\} *$ \\
\hline$E$. of difference & 0.01 & $3 \cdot 7$ & 0.91 & 0.79 & 0.88 \\
\hline
\end{tabular}

NS, Not significant.

Signiflcant difference at $P=0.01$

† Significant difference at $P=0 \cdot 001$.

It is clcar that, in certain circumstances, the digestibility of a grass variety may be substantially influenced by changes in cobalt content. It seems that in the present experiments the increase in liveweight gain noted in lambs offered the + Co Reveille herbage may bo attributed largcly to its greater digestibility. The fact that the additional cobalt did not influence liveweight gain over the first six weeks of feeding suggests that the difference in digestibility arose after the sixth weck and that the effect may be caused by change in the rumen flora. A surprising feature of the results is that further cobalt did not affect the digestibility of the RVP ryegrass, although it contained less cobalt than the Reveille. This may indicate a difference in the availability of cobalt in the two varieties, and requires further investigation.

These experiments are being continued, but there are several implications already. In certain circumstances, the provision of extra cobalt seems to stimulate rumen activity and to increase fibre digestion. In herbage cvaluation using in vitro digestion techniques, changes in the digestibility of varieties as a result of mineral deficiencies may not necessarily be found, for the inoculum used may be rich in cobalt. Finally, improved animal production may be possible by the application of traco amounts of cobalt to certain herbage varictics.

I thank Professor P. T. Thomas for his interest in this work and Mr Roy Hughes and his colleagues in the Agronomy Department for their collaboration.

\section{T. H. JONES}

Welsh Plant Breeding Station,

Aberystwyth.

Received February 20; reviscd April 7, 1970.

${ }^{1}$ Underwood, E. J., The Mineral Nutrition of Livestock, 147 (FAO and CAB, 1966).

"Marston, H. R., Allen, S. H., and Smith, R. M., Nature, 190, 1085 (1961).

s Hine, D. C., and Dewbarn, M. C., Austral. J. Exp. Biol. Med. Sci., 32, 641 (1954).

4 Gall, L. S., Smith, s. E., Becker, 1). E., Stark, C. K., and Loosli, J. K., Science, 109,468 (1949).

'Krelowska, M., Acta Agrar. Silvest. Ser. Zootech., 6, 3, 19 (1966).

- Madjanov, A. V., Raeckaja, J. I., and Holmanov, A. M., Trudy Vses. Natc-Issled. Inst. Zinotnovodstra, 24, 203 (1962).

? Becker, D. E., and Smith, S. E., J. Nutr, 43, 87 (1951).

${ }^{8}$ Andrews, F. D., Stephenson, B. J., Anderson, J. P., and Faithful, W. C., 